\title{
Efficacy of a Nonpathogenic Acidovorax citrulli Strain as a Biocontrol Seed Treatment for Bacterial Fruit Blotch of Cucurbits
}

K. L. Johnson, Department of Plant Pathology, University of Georgia, Athens 30602; G. V. Minsavage, Department of Plant Pathology, University of Florida, Gainesville 32611; T. Le, Department of Plant Pathology, University of Georgia; J. B. Jones, Department of Plant Pathology, University of Florida; and R. R. Walcott, Department of Plant Pathology, University of Georgia

\begin{abstract}
Johnson, K. L., Minsavage, G. V., Le, T., Jones, J. B., and Walcott, R. R. 2011. Efficacy of a nonpathogenic Acidovorax citrulli strain as a biocontrol seed treatment for bacterial fruit blotch of cucurbits. Plant Dis. 95:697-704.

Bacterial fruit blotch (BFB), caused by the seedborne, gram-negative bacterium Acidovorax citrulli, is a serious threat to cucurbit seed and fruit production worldwide. Because of the lack of effective management strategies, we investigated the efficacy of a nonpathogenic $A$. citrulli strain as a biological control seed treatment for BFB. For this study, we generated a type III secretion system mutant of A. citrulli, AAC00-1 $\Delta h r c C$, that was nonpathogenic on watermelon but retained its ability to colonize germinating watermelon seed. With watermelon seed naturally infested with $A$. citrulli, AAC00-1 $\Delta h r c C$ reduced BFB seedling transmission by $81.8 \%$ relative to control seed. In comparison,

another A. citrulli antagonist, A. avenae strain AAA 99-2, reduced BFB seedling transmission by $74.6 \%$ for seed samples from the same lot. Additionally, when female watermelon blossoms were protected with AAC00-1 $4 h r C$ and subsequently challenged with AAC00-1, the resulting seedlots displayed $8 \%$ BFB seedling transmission. This was not significantly different than seed from blossoms protected with AAA 99-2 (4\%) but significantly less than those from blossoms protected with $0.1 \mathrm{M}$ phosphate-buffered saline (36\%). These results suggest that nonpathogenic A. citrulli has potential as a biological control seed treatment component in a comprehensive BFB management program.
\end{abstract}

Bacterial fruit blotch (BFB) of cucurbits, caused by the gramnegative bacterium Acidovorax citrulli (33) (formerly A. avenae subsp. citrulli; 42), poses a significant threat to cucurbit seed and fruit production worldwide (32). BFB was reported in commercial watermelon fields in Florida in 1989, and frequent outbreaks caused significant economic losses across the southeastern United States in the early 1990s (35). At present, the disease is a sporadic threat to cucurbit producers worldwide $(4,26,29)$, because an outbreak can lead to $100 \%$ yield loss under ideal environmental conditions.

Seed are the most important source of primary inoculum for $A$. citrulli and infested seed can readily initiate BFB epidemics under transplant house conditions (18). Watermelon seed can become infested via infection of immature fruit through open stomata (up to 3 weeks after anthesis) or by bacterial penetration of the pistil of female flowers $(10,40)$. Commercial seed producers bear the responsibility for producing A. citrulli-free seed to limit BFB outbreaks. To date, the most effective strategy for managing BFB has been excluding the pathogen from seed, fruit, and transplant production systems. This involves producing seed in regions of countries with cool, dry climates that limit BFB development, combined with visual seed field inspection and rigorous seed health testing (40). Seed treatments, including disinfestants and fermentation, are also routinely employed $(15,16)$; however, because the pathogen can be localized under the seed coat (30), the efficacy of externally applied seed treatments can vary widely $(16,30)$.

Currently, there are no commercially available BFB-resistant watermelon cultivars. Early reports of resistance in some cultivars were disputed and, although five cultivars with BFB resistance were reported, the horticultural traits of these lines were undesirable (17). Identification of effective resistant cultivars is further

Corresponding author: R. Walcott, E-mail: rwalcott@uga.edu

Accepted for publication 10 February 2011.

doi:10.1094/PDIS-09-10-0660

(C) 2011 The American Phytopathological Society complicated by the fact that $A$. citrulli can infect all growth stages of the watermelon plant, and the level of resistance may vary depending on the plant stage being screened and the bacterial strains used. For example, Bahar et al. recently reported that, whereas certain melon cultivars had BFB-tolerant foliage, the BFB seed-toseedling transmission rates were still high (2). In the absence of resistance there is a need to develop a comprehensive integrated disease management strategy for BFB. One environmentally sound component that could be incorporated into this strategy is biological control seed treatments.

Biological control has been previously explored for BFB management $(9,25,41)$. Fessehaie and Walcott (9) demonstrated that seed treatments with $A$. avenae (formerly $A$. avenae subsp. avenae; 33) strain AAA99-2, a pathogen of maize, reduced BFB seed-toseedling transmission (9). Additionally, when applied as a protectant to female watermelon blossoms, the bacterium significantly reduced A. citrulli seed infestation. Because AAA 99-2 was pathogenic on maize, it was unsuitable as a commercial seed treatment for BFB. One approach for developing a more suitable BFB biocontrol candidate is the generation of a nonpathogenic $A$. citrulli strain. Nonpathogenic strains of phytopathogens have been used previously to manage plant diseases $(27,37,38)$. These strains can occur naturally or can be generated by mutagenesis. One strategy that can efficiently abolish pathogenicity in phytobacteria is mutagenesis of the type III secretion system (T3SS) (3,5). Type III secretion (T3S) is important for pathogenesis because it facilitates the translocation of virulence proteins from the bacterial cell directly into the cytoplasm of the host plant cell (13). Mutations in critical T3SS genes result in loss of pathogenicity and the ability to induce the hypersensitive response (HR) in nonhost plants (21). The use of T3SS mutants as biocontrol agents has been reported for Xanthomonas campestris pv. vesicatoria and Erwinia amylovora $(27,37)$, the causal agents of bacterial spot of pepper and fire blight of pear and apple, respectively. However, there have been no attempts to develop a biocontrol seed treatment for BFB based on a T3SS A. citrulli mutant. Hence, the objective of this study was to develop and assess the efficacy of a T3SS mutant of $A$. citrulli as a biocontrol seed treatment for BFB. 


\section{Materials and Methods}

Bacterial cultures, media, and inoculum preparation. $A$. citrulli, A. avenae, and Escherichia coli strains used in this study are listed in Table 1. A. citrulli and A. avenae strains were routinely grown on nutrient agar (Difco, Becton Dickinson and Co., Sparks, MD) with appropriate antibiotics for $48 \mathrm{~h}$ at $28^{\circ} \mathrm{C}$. E. coli strains were grown in Luria Bertani (LB) broth or agar (Difco) with appropriate antibiotics for $24 \mathrm{~h}$ at $37^{\circ} \mathrm{C}$. To prepare A. citrulli inoculum, bacterial cells were pelleted from $1.5 \mathrm{ml}$ of overnight LB broth culture by centrifugation at 13,000 rpm for $1 \mathrm{~min}$. Cells were washed with and resuspended in $0.1 \mathrm{M}$ phosphate-buffered saline (PBS; $137 \mathrm{mM} \mathrm{NaCl}, 5.6 \mathrm{mM} \mathrm{Na} \mathrm{HPO}_{4}, 2.7 \mathrm{mM} \mathrm{KCl}$, and 1.5 $\mathrm{mM} \mathrm{KH_{2 }} \mathrm{PO}_{4}$ ). Bacterial suspensions containing approximately $1 \times$ $10^{8} \mathrm{CFU} / \mathrm{ml}$ were estimated using a spectrophotometer (optical density at $600 \mathrm{~nm}$ of approximately 0.3 ) (Spectronic 20; Bausch and Lomb, Rochester, NY) and 10-fold serially diluted with PBS to generate cell suspensions with desired concentrations. When used, antibiotics were incorporated into media at the following concentrations: rifamycin $(100 \mu \mathrm{g} / \mathrm{ml}$, A citrulli $)$, spectinomycin $(100 \mu \mathrm{g} / \mathrm{ml}$, A. citrulli and E. coli), kanamycin $(50 \mu \mathrm{g} / \mathrm{ml}, A$. citrulli and E. coli), and cycloheximide $(200 \mu \mathrm{g} / \mathrm{ml}$, A. citrulli) (Sigma-Aldrich, St. Louis).

DNA manipulations. A nonpathogenic A. citrulli T3SS mutant (AAC00-1 $\Delta h r c C$ ) was generated by deletion of the $h r c C$ gene that encodes the T3SS outer membrane pore (22). Briefly, a 3.6-kb fragment containing the $h r c C$ gene was identified in the genome library of AAC00-1. The 3.6-kb fragment was digested from a cosmid clone using BamHI (Promega Corp., Madison, WI), cloned into pBluescript, and transformed into E. coli strain DH5 $\alpha$. In all, $673 \mathrm{bp}$ were deleted from the cloned fragment by restriction digestion with StuI and BstEII (Promega Corp.) and the fragment was religated, resulting in deletion of the $h r c C$ gene. The flanking open reading frames, SAM methyl transferase and $h r p D 5$, remained unaffected. The deleted $h r c C$ gene construct was cloned into the suicide vector pOK1, which carries the levansucrase $S a c B$ gene, to generate pOK-HRCC. pOK-HRCC was transformed into E. coli strain S17-1 ( $\lambda$ pir), which was mated with AAC00-1, and singlecrossover transconjugants were selected based on resistance to spectinomycin. A second homologous recombination was promoted by growth on M9 agar plates containing sucrose, which retards the growth of bacteria expressing $S a c B$. Generation of the deletion mutation was confirmed by polymerase chain reaction (PCR) amplification using primers HrcC.for (5'-TGTATTTCT ACCCGGGCAAGTCC- $3^{\prime}$ ) and HrcC.rev (5'-TCCTCGATGTAG AGACTCAGCTTG-3'). One $h r c C$ deletion mutant, designated AAC00-1 $\Delta h r c C$, was suitable for our studies. The $h r c C$ deletion mutant was complemented by subcloning the 3.6-kb BamHI fragment containing the $h r c C$ gene into the cosmid pUFR043 to pro- duce pUFR034- $h r c C$. pUFR043- $h r c C$ was subsequently transformed into $E$. coli $\mathrm{S} 17-1$ ( $\lambda$ pir) for use in triparental mating. pUFR043- $h r c C$ was then transformed into AAC00-1 $h h r c C$ to create AAC00-1 $\Delta h r c C$ comp ( $h r c C$ mutation complement).

Pathogenicity and HR assays. The effect of $h r c C$ deletion on the ability of $A$. citrulli to induce an HR was evaluated using 6week-old tobacco plants (Nicotiana tabacum). Using a hypodermic syringe without a needle, AAC00-1, AAC00-1 $4 h r c C$, AAC00$1 \Delta h r c C$ comp at approximately $1 \times 10^{8} \mathrm{CFU} / \mathrm{ml}$, or PBS was infiltrated into the intercellular spaces between the major veins of a fully expanded tobacco leaf. Plants were incubated under conditions of approximately $75 \%$ relative humidity $(\mathrm{RH}), 28^{\circ} \mathrm{C}$, and 12 $\mathrm{h}$ of fluorescent light daily in a growth chamber (Percival, Perry, IA) for 2 days. Plants were subsequently observed for cell death associated with a typical HR. To determine the effect of the T3SS mutation on A. citrulli pathogenicity, 2-week-old watermelon seedlings ('Sugar Baby') were infiltrated as described above with AAC00-1 $h r c C$, AAC00-1 $h r r C$ comp AAC00-1 (wild-type) at approximately $1 \times 10^{6} \mathrm{CFU} / \mathrm{ml}$, or PBS as a negative control. The cotyledons of three seedlings were inoculated (28) and plants were incubated for 2 days at $28^{\circ} \mathrm{C}$ with approximately $75 \% \mathrm{RH}$ and $12 \mathrm{~h}$ of fluorescent light daily in a growth chamber. Plants were then visually observed for BFB symptoms (necrosis and water soaking). This experiment was conducted three times.

Role of T3SS in A. citrulli colonization of watermelon seed during germination. The ability of AAC00-1 $\mathrm{ArcC}$ to colonize watermelon seed (Sugar Baby) during seed germination was determined by infiltrating seed with AAC00-1, AAC00-1 $\Delta h r c C$, or AAC00-1 $\Delta h r c C$ comp at approximately $1 \times 10^{3} \mathrm{CFU} / \mathrm{ml}$ as previously described (39). Watermelon seed $(n=35)$ were planted in plastic boxes (Tri-State Plastics, Dixon, KY) on moist blotter paper (Hoffman Manufacturing, Albany, OR) and incubated at $30^{\circ} \mathrm{C}$ with $100 \%$ RH and continuous fluorescent light. Seed samples $(n=5$ seeds) were collected at $0,6,12,24,48,72$, and $96 \mathrm{~h}$ after planting and bacterial populations were estimated by macerating each seed in $900 \mu \mathrm{l}$ of PBS in a sterile microcentrifuge tube. Appropriate 10fold serial dilutions $(100 \mu \mathrm{l})$ of each seed homogenate were spotted onto nutrient agar plates with appropriate antibiotics. Plates were incubated for 48 to $72 \mathrm{~h}$ at $28^{\circ} \mathrm{C}$ and, subsequently, A. citrulli colonies were enumerated. The experiment was conducted three times and mean bacterial populations were plotted over time to generate area under population dynamics curves (AUPDCs). Analysis of variance (ANOVA) was conducted on AUPDC data using JMP statistical analysis software (version 8 for Windows; SAS Institute Inc, Cary, NC) and the effect of the T3SS mutation on colonization of watermelon seed was determined using Tukey-Kramer's honestly significant difference (HSD).

Role of T3S in A. citrulli virulence. To determine the role of $\mathrm{T} 3 \mathrm{~S}$ in virulence, suspensions with $\mathrm{AAC} 00-1, \mathrm{AAC} 00-1 \Delta h r c C$, or

Table 1. Bacterial strains and plasmids used in this study

\begin{tabular}{|c|c|c|}
\hline Strains and plasmids & Relevant characteristics ${ }^{\mathbf{a}}$ & Source \\
\hline \multicolumn{3}{|l|}{ Bacteria } \\
\hline \multicolumn{3}{|c|}{ Acidovorax citrulli (AAC) } \\
\hline $00-1$ & Wild-type, $\mathrm{Rf}^{\mathrm{r}}$ & 9 \\
\hline $00-1 \Delta h r c C$ & hrcC deletion mutant & This study \\
\hline $00-1 \Delta h r c C$ comp & hrcC complemented mutant & This study \\
\hline \multicolumn{3}{|l|}{ A. avenae (AAA) } \\
\hline $99-2$ & Maize pathogen & 9 \\
\hline \multicolumn{3}{|l|}{ Escherichia coli } \\
\hline DH5 $\alpha$ & $\begin{array}{l}\mathrm{F}-\text { Ф80lacZuM15 } \Delta \text { (lacZYA-argF) } \mathrm{U} 169 \text { rec } \mathrm{A} 1 \text { end } \mathrm{A} 1 \text { hsdR17 (rK-, mK+) } \\
\text { phoA sup } 44 \lambda \text { - thi-1 gyrA96 relA1 }\end{array}$ & Invitrogen \\
\hline S17-1 ( $\lambda$ pir $)$ & 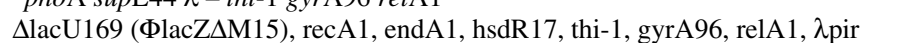 & Jeff Jones, UFL \\
\hline \multicolumn{3}{|c|}{ 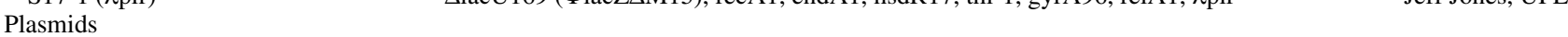 } \\
\hline pBluescript & $A p^{r}$ & Invitrogen \\
\hline pOK1 & $\mathrm{Sp}^{\mathrm{r}}, \mathrm{SacB}$ & 19 \\
\hline pOK-HRCC & truncated $h r c C$ gene construct in $\mathrm{pOK} 1$ & This study \\
\hline pUFR043 & $\mathrm{Gm}^{\mathrm{r}}, \mathrm{Km}^{\mathrm{r}}$ & 8 \\
\hline pUFR043- $h r c C$ & Complete $h r c C$ gene in pUFR043 & This study \\
\hline
\end{tabular}

${ }^{\mathrm{a}} \mathrm{Rf}^{\mathrm{r}}, \mathrm{Ap}^{\mathrm{r}}, \mathrm{Sp}^{\mathrm{r}}, \mathrm{Gm}^{\mathrm{r}}$, and $\mathrm{Km}^{\mathrm{r}}=$ resistant to rifamycin, ampicillin, spectinomycin, gentamycin, and kanamycin, respectively. 
AAC00-1 $\Delta h r c$ Ccomp at approximately $1 \times 10^{3} \mathrm{CFU} / \mathrm{ml}$ were infiltrated separately into the cotyledons of three 2 -week-old watermelon seedlings (Sugar Baby). Infiltrated leaves were allowed to air dry for $1 \mathrm{~h}$; then, six leaf discs, $3 \mathrm{~mm}$ each (one from each cotyledon) were collected at $1,12,24,48,72$, and $96 \mathrm{~h}$ after inoculation. Each leaf disc was macerated in a separate microcentrifuge tube containing $900 \mu \mathrm{l}$ of PBS and bacterial populations were enumerated by serial dilution plating as described above. The experiment was conducted three times and bacterial populations were plotted over time to generate AUPDC data. AUPDC data were used to compare the effect of the T3SS mutation on A. citrulli virulence using Tukey-Kramer's HSD.

Efficacy of AAC00-1 $\Delta h r c C$ as a biocontrol seed treatment for BFB under growth chamber conditions. To evaluate the efficacy of AAC00-1 $\Delta h r c$ as a biocontrol seed treatment, naturally infested seed extracted from symptomatic watermelon fruit from a BFB outbreak in Reidsville, GA in 2005 were used. Samples (four replicates of 100 seeds) of this seedlot displayed $75 \%$ mean BFB seedling transmission and $76 \%$ mean germination using a modified seedling grow-out assay (40). Infested seed $(n=100)$ were incubated in $20 \mathrm{ml}$ of cell suspension containing AAC00-1 $\Delta h r c$, AAA 99-2 at approximately $1 \times 10^{8} \mathrm{CFU} / \mathrm{ml}$, or PBS as a negative control. Watermelon seed were then subjected to continuous vacuum infiltration for $20 \mathrm{~min}$, which allowed the biocontrol agents to be deposited under the testae. After inoculation, seed were air dried at approximately $25^{\circ} \mathrm{C}$ for $24 \mathrm{~h}$ and then assayed for BFB seed-toseedling transmission using a modified seedling grow-out assay. Briefly, seed $(n=100)$ were planted in transparent plastic boxes on two layers of blotter paper (Hoffman Manufacturing) saturated with deionized water. Germination boxes were incubated in a growth chamber (Percival) under conditions of $100 \% \mathrm{RH}, 30^{\circ} \mathrm{C}$, and continuous fluorescent light for 12 days. Seed were monitored daily and germination percentage (number of seed that produced radicles and plumules divided by the total number of seed planted $\times 100$ ) and BFB seedling transmission (number of seedlings displaying typical BFB symptoms divided by the number of seedlings that germinated $\times 100$ ) percentages were recorded daily. The experiment was conducted twice and mean BFB seedling transmission percentage data were plotted over time to generate AUDPC data. AUDPC data were used to conduct ANOVA and to determine the significance of the effect of AAC00-1 $\Delta h r c C$ on BFB seedling transmission using Tukey-Kramer's HSD. Seed germination data were used to determine the effect of AAC00-1 $\Delta h r c C$ on seed physiology. The ability of AAC00-1 $4 h r C$ and AAA 99-2 to limit BFB seedling transmission was determined using the formula described by Moss et al. (27).

Efficacy of AAC00-1 $\Delta h r c C$ as a biocontrol seed treatment for BFB under greenhouse conditions. Infested watermelon seed ('Crimson Sweet') were generated by hand pollinating (rubbing pollen from male blossoms onto the stigmatic surfaces), then inoculating the stigmas of female blossoms of greenhouse-grown plants with AAC00-1 (approximately $1 \times 10^{8} \mathrm{CFU} / \mathrm{ml}$ ) (40). Samples (four replicates of 100 seeds) of this seedlot displayed $75 \%$ mean BFB seedling transmission and $72 \%$ mean germination using a modified seedling grow-out assay (40). Fruit from inoculated blossoms were allowed to develop to maturity (35 days after anthesis) and seed were extracted by hand. After extraction, seed were air dried at $25^{\circ} \mathrm{C}$ for $24 \mathrm{~h}$ and samples $(n=100$ seed) were vacuum-infiltrated with AAC00-1 $\Delta h r C$ at approximately $1 \times$ $10^{8} \mathrm{CFU} / \mathrm{ml}$ or PBS as a negative control as described above. Treated seed were air dried at approximately $25^{\circ} \mathrm{C}$ for $24 \mathrm{~h}$ and then assayed for BFB seed-to-seedling transmission under greenhouse conditions as follows. Seed $(n=100)$ were planted in 128-cell polystyrene flats (Speedling Inc., Sun City, FL) filled with pasteurized potting mix $(90 \%$ composted pine bark and $10 \%$ vermiculite). Flats were incubated in plastic chambers (on a greenhouse bench) used to generate conditions of $30^{\circ} \mathrm{C}$ and approximately $100 \% \mathrm{RH}$ for 21 days. Seedlings were monitored daily and germination and BFB seedling transmission percentages were recorded. The experiment was conducted three times and mean BFB seedling transmission percentages were plotted over time to generate AUDPC data. AUDPC data were used to conduct ANOVA and to determine the significance of the effect of AAC00-1 $\Delta h r c$ on BFB seedling transmission using the Student's $t$ test.

Efficacy of AAC00-1 $\Delta h r c C$ as a blossom protectant to prevent seed infestation by $\boldsymbol{A}$. citrulli. The ability of AAC00-1 $\mathrm{hrcC}$ to protect female blossoms from invasion by $A$. citrulli was evaluated. Watermelon plants (Crimson Sweet) were maintained under standard greenhouse conditions in 15 -liter pots containing $90 \%$ composted pine bark and $10 \%$ vermiculite until anthesis. At anthesis, female blossoms were manually pollinated as described above, then immediately inoculated by depositing $10 \mu \mathrm{l}$ of a suspension containing AAC00-1 $4 h r c$, AAA99-2 at approximately $1 \times 10^{8}$ $\mathrm{CFU} / \mathrm{ml}$, or PBS as a negative control onto the stigmas. Five hours after inoculation, blossoms were challenged with $10 \mu \mathrm{l}$ of a cell suspension containing AAC00-1 at $1 \times 10^{9} \mathrm{CFU} / \mathrm{ml}$. Each treatment was applied to 10 blossoms, each on a separate plant, and fruit were allowed to develop for 35 days after pollination. At harvest maturity, fruit were surface sterilized and seed were manually extracted (seed from each fruit were maintained as a separate lot), air dried at $25^{\circ} \mathrm{C}$ for $24 \mathrm{~h}$, and stored at $4^{\circ} \mathrm{C}$. To determine the level of seed infestation by A. citrulli, samples $(n=$ 100 seed) from each lot were subjected to the modified seedling grow-out assay as described above. Seedlings were monitored daily for 14 days and germination and BFB seedling transmission percentages were recorded daily. This experiment was conducted twice and mean BFB seedling transmission percentage data were plotted over time and used to generate AUDPC data. Germination data were also collected and used to determine the effect of biocontrol blossom treatments on seed physiology. AUDPC data were analyzed using the Tukey-Kramer's HSD to determine the significance of blossom protection on seed infestation by $A$. citrulli.

Efficiency of seed treatment via female watermelon blossom inoculation. To determine whether blossom inoculation was an efficient method for inoculating seed with biocontrol agents, female blossoms were inoculated with AAC00-1 $\Delta h r c C$ and the resulting seed were assayed for the bacterium by species-specific quantitative real-time PCR. Watermelon plants (Crimson Sweet) were cultivated under greenhouse conditions in 15-liter pots as described above. At anthesis, female blossoms were hand pollinated and stigmas were immediately inoculated with $10 \mu \mathrm{l}$ of a suspension of AAC00-1 $\Delta h r c$ or AAC00-1 at approximately $1 \times$ $10^{8} \mathrm{CFU} / \mathrm{ml}$ as described above. Inoculated blossoms were allowed to develop to harvest maturity (approximately 35 days after anthesis). For each treatment, five mature fruit were harvested and seed were extracted and stored at $4^{\circ} \mathrm{C}$. The level of seed infestation was determined by extracting total microbial DNA from seed and conducting quantitative real-time PCR as follows. Seed $(n=50)$ were macerated for 5 min using a homogenizer (Bioreba Homex 6; Bioreba, Gilroy, CA) and suspended in $10 \mathrm{ml}$ of PBS. The suspension $(1 \mathrm{ml})$ was pelleted by centrifugation at $13,000 \mathrm{rpm}$ for $3 \mathrm{~min}$. The PBS was decanted and total microbial DNA was extracted from the pellet using a Mobio Ultraclean Microbial DNA isolation kit (Mobio Laboratories Inc., Carlsbad, CA), according to the manufacturer's instructions. Extracted DNA was dissolved in $20 \mu$ of water and $5 \mu \mathrm{l}$ was used for real-time PCR. For real-time PCR, the master-mix comprised $12.5 \mu$ of Bio-Rad real-time PCR mastermix (Bio-Rad Laboratories, Hercules, CA), 7.5 pM BOXAACF and BOXAACR 2 primers, and $5 \mathrm{pM}$ TaqMan probe (11). Thermal cycling conditions included denaturation at $95^{\circ} \mathrm{C}$ for 2 min., $35 \mathrm{cy}-$ cles of denaturation at $95^{\circ} \mathrm{C}$ for $15 \mathrm{~s}$, and annealing and extension at $55^{\circ} \mathrm{C}$ for $45 \mathrm{~s}$. The experiment was conducted twice and mean cycle threshold $(\mathrm{Ct})$ values were recorded. A standard curve was generated using 10-fold serial dilutions of $A$. citrulli cell suspensions $\left(1 \times 10^{8}\right.$ to $\left.1 \times 10^{0} \mathrm{CFU} / \mathrm{ml}\right)$. An amplification threshold value of 30 fluorescence units was routinely used, and the standard curve was based on four independent replicates. The standard curve was constructed by plotting mean $\mathrm{Ct}$ values against $\log _{10} A$. 
citrulli cell dilutions and it was used to estimate $A$. citrulli populations in seed. The effect of the T3SS on colonization of watermelon seed tissue via blossoms was determined using the Student's $t$ test.

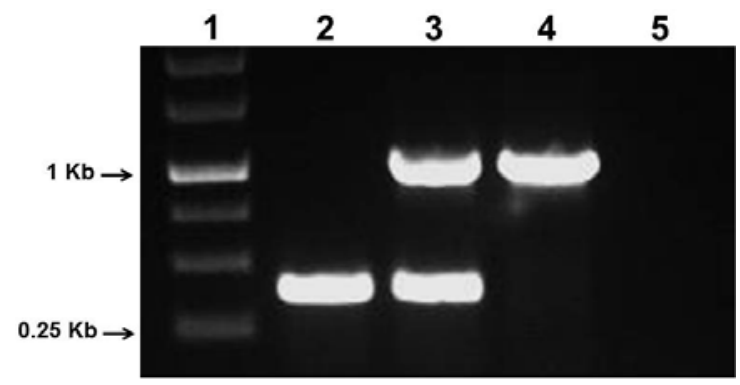

Fig. 1. Ethidium bromide-stained agarose gel of polymerase chain reaction amplicons confirming the deletion of the hrcC gene in Acidovorax citrulli strain 00-1. Lane 1, 1-kb DNA ladder (Fermentas, Glen Burnie, MD); lane 2, AAC00-1 $4 h r c C$ (nonpathogenic hrcC mutant of AAC00-1); lane 3, AAC00-1 $\Delta$ hrcCcomp (complemented hrcC mutant of AAC00-1); lane 4, AAC00-1 (wild-type A. citrulli); lane 5, water (negative control).

\section{Results}

Generation and characterization of a T3SS mutant of $A$. citrulli. Deletion of the AAC00-1 hrcC gene was confirmed by PCR amplification (Fig. 1). Using primers for the $h r c C$ gene, a 1.08-kb DNA fragment was amplified from wild-type AAC00-1 and the complemented strain, AAC00-1 $\Delta h r c C$ comp. However, the $1.08-\mathrm{kb}$ fragment was absent from AAC00-1 $\Delta h r c \mathrm{C}$ and a smaller 0.4-kb fragment was amplified, indicating deletion of the $h r c C$ gene. As expected, both amplicons were produced with DNA from AAC00-1 $\Delta h r c C$ comp (Fig. 1). $h r c C$ deletion resulted in the loss of T3S in AAC00-1, which was confirmed by lack of an HR when AAC00-1 $\Delta h r c C$ was infiltrated into tobacco leaves (Fig. 2A). In contrast, AAC00-1 (wild-type) and AAC00-1 $\Delta h r c C$ comp induced a typical HR on tobacco leaves (Fig. 2A). As expected, leaf infiltrations with PBS did not yield an HR on tobacco. When infiltrated into watermelon seedlings, AAC00-1 and AAC00-1 $4 h r c$ comp produced typical water-soaking and necrosis by 2 days post inoculation (dpi) (Fig. 2B). In contrast, seedlings infiltrated with AAC00-1 $\Delta h r c C$ did not develop BFB symptoms and yielded results that were comparable with seedlings inoculated with PBS (Fig. 2B).
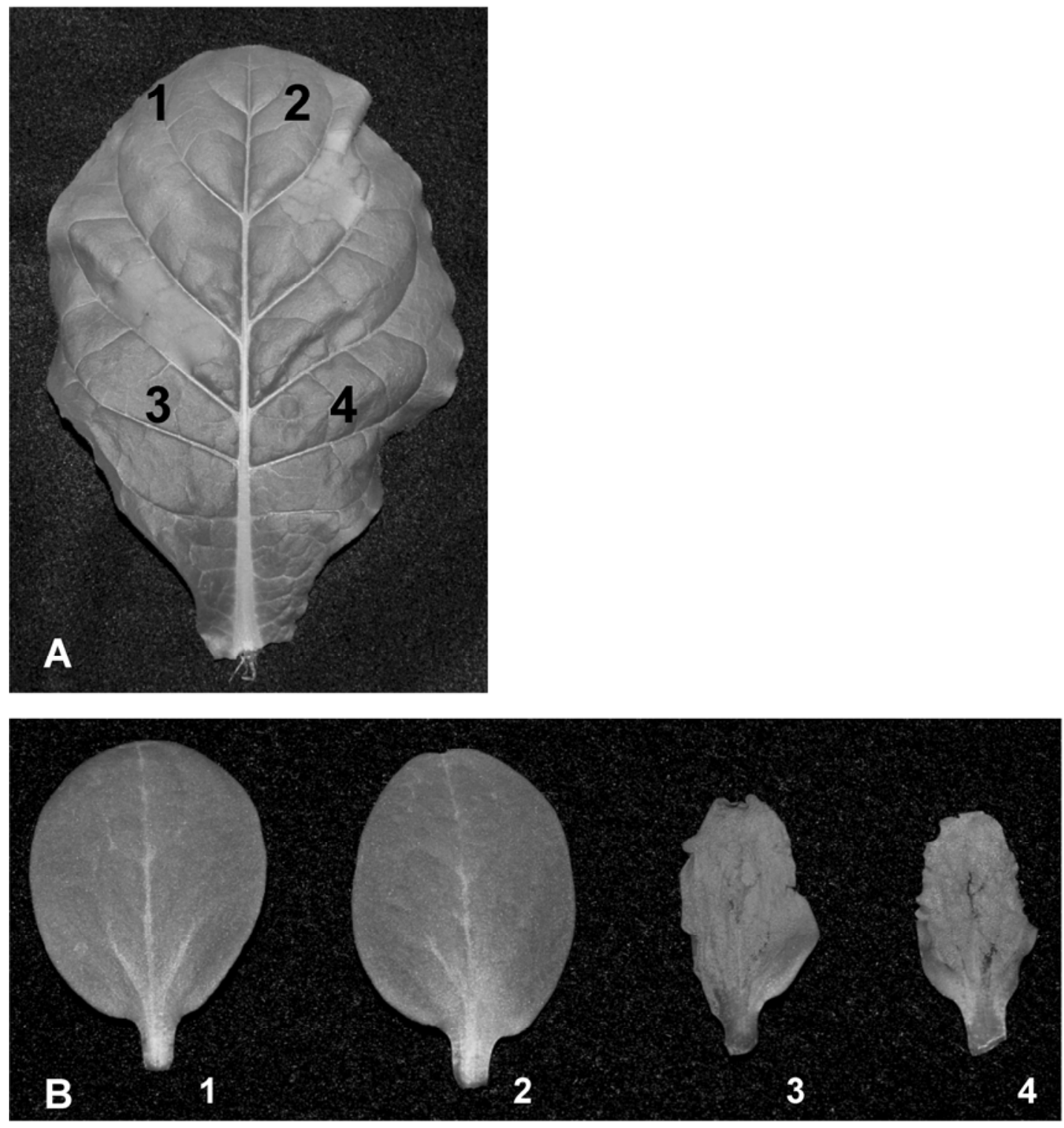

Fig. 2A, Induction of the hypersensitive response on tobacco (Nicotiana tabacum) by different Acidovorax citrulli strains. Leaves were infiltrated with 1, AAC00-1 $\Delta$ hrcC (nonpathogenic hrcC mutant of AAC00-1); 2, AAC00-1 $\mathrm{h}$ rcCcomp (complemented hrcC mutant of AAC00-1); 3, AAC00-1 (wild-type A. citrulli); and 4, 0.1 M phosphatebuffered saline (PBS, negative control) at $1 \times 10^{6} \mathrm{CFU} / \mathrm{ml}$. B, Response of 2-week-old watermelon ('Crimson Sweet') cotyledons infiltrated with different $A$. citrulli strains, including: 1, PBS (negative control); 2, AAC00-1 $\Delta$ hrCC; 3, AAC00-1 $\Delta$ hrCCcomp; and 4, AAC00-1. 
Role of T3S in $A$. citrulli colonization of watermelon seed during germination. Both AAC00-1 $4 h r C$ and AAC00$1 \Delta h r c C$ comp colonized watermelon seed at wild-type levels during the first $96 \mathrm{~h}$ of germination. For all strains, populations increased on watermelon seed by $6 \mathrm{~h}$ after planting (Fig. 3A). AAC00$1 \Delta h r c C$ and AAC00-1 $h h r c C$ comp increased continuously over the course of the experiment ( $96 \mathrm{~h}$ ), similar to AAC00-1. By $96 \mathrm{~h}$ after planting, the mean populations of AAC00-1, AAC00-1 $\Delta h r c C$, and AAC00-1 $\Delta h r c C$ comp were $1.7 \times 10^{9}, 3.9 \times 10^{8}$, and $1.6 \times 10^{9}$ $\mathrm{CFU} / \mathrm{g}$ of seed, respectively (Fig. 3A). For seed inoculated with AAC00-1 and AAC00-1 $\Delta h r c$ Comp, seedlings emerged and developed typical BFB symptoms on cotyledons by 14 days after planting (dap). In contrast, seedlings from seed inoculated with AAC00$1 \Delta h r c C$ emerged and remained asymptomatic by 14 dap. ANOVA conducted on AUPDC data indicated that the effect of experiment was not statistically significant $(P=0.94)$; therefore, data from three experiments were pooled and analyzed. There was no significant difference in the colonization of watermelon seed by AAC00$1 \Delta h r c C$, AAC00-1, and AAC00-1 $4 h r c C$ comp according to TukeyKramer's HSD $(P=0.19$; Fig. 3B).

Role of T3S in A. citrulli virulence. Populations of AAC00-1 and AAC00-1 $\Delta h r c$ Ccomp increased continuously over the first 96 $\mathrm{h}$ after inoculation. Populations of both strains increased from ap-
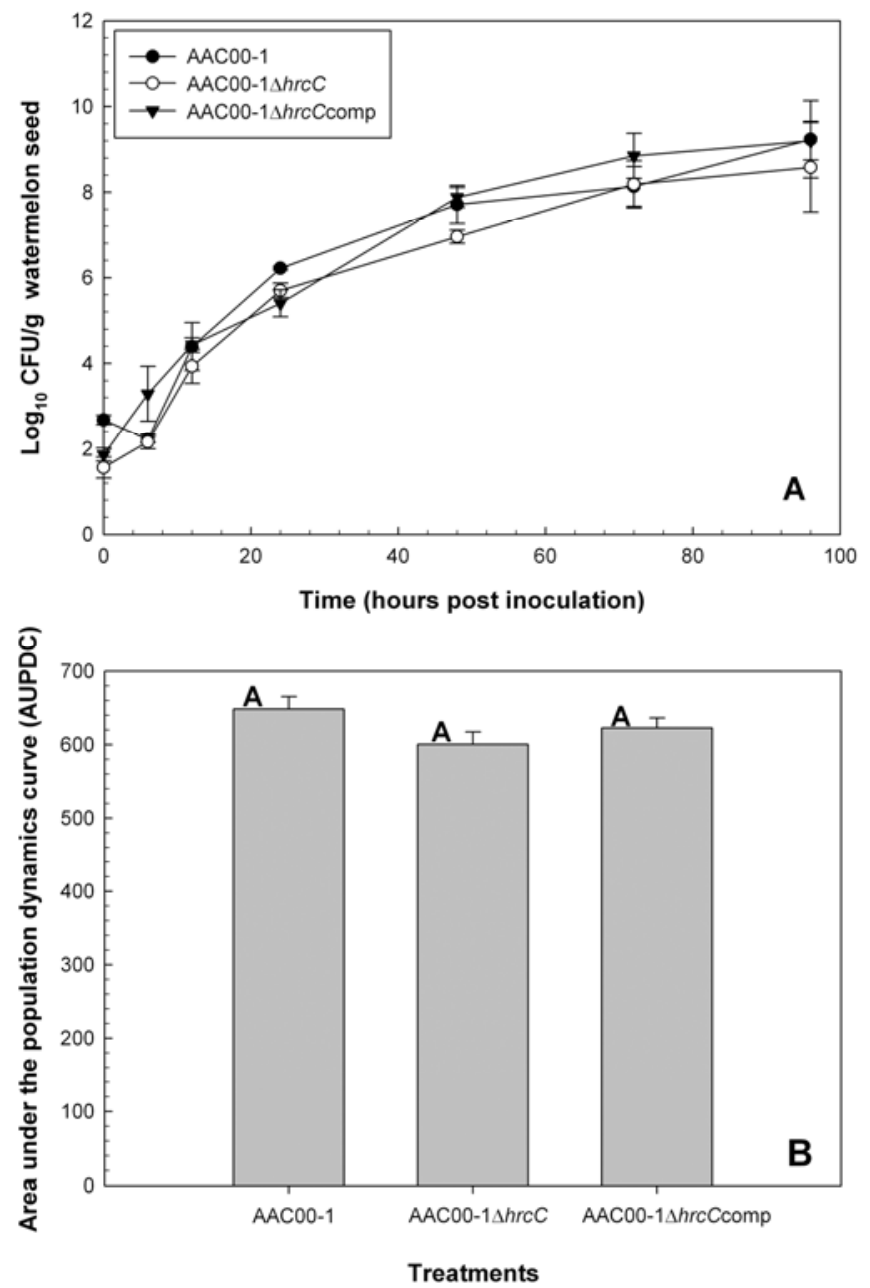

Fig. 3A, Colonization of watermelon seed ('Sugar Baby') by wild-type Acidovorax citrulli (AAC00-1), AACO0-1 4 hrCC (nonpathogenic hrcC mutant), or AACO0$1 \Delta h r c C$ comp (complemented $h r c C$ mutant) during the first $96 \mathrm{~h}$ of seed germination. The experiment was conducted three times and each data point represents the mean of the three experiments $(n=5$ seed). Lines represent the standard error of the mean. B, Bar chart of area under population dynamics curve (AUPDC) calculated for seed infiltrated with $10^{3}$ CFU of AAC00-1, AAC00-1 4 hrCC, or AACO0$1 \Delta h r c C c o m p$ and germinated for $96 \mathrm{~h}$. Bars represent mean AUPDC and lines indicate standard error of the means. Treatments with similar letters are not significantly different according to Tukey-Kramer's honestly significant difference. proximately $1 \times 10^{1} \mathrm{CFU} /$ disc at $1 \mathrm{~h}$ post inoculation (hpi) to $1 \times$ $10^{3} \mathrm{CFU} / \mathrm{disc}$ by $24 \mathrm{hpi}$. On the other hand, populations of AACOO$1 \Delta h r c C$ remained at $1 \times 10^{1} \mathrm{CFU} /$ disc for the first $72 \mathrm{hpi}$. AAC001 and AAC00-1 $\Delta h r c C$ comp colonized watermelon cotyledons at similar rates and reached mean populations of $2.2 \times 10^{7}$ and $4.3 \times$ $10^{6} \mathrm{CFU} /$ disc, respectively, by $96 \mathrm{hpi}$ (Fig. 4A). In contrast, AAC00-1 $\Delta h r c C$ reached a population of $2.0 \times 10^{2} \mathrm{CFU} /$ disc by 96 hpi (Fig. 4A). The effect of the T3SS on A. citrulli colonization of watermelon cotyledons was statistically significant $(P<0.01)$ (Fig. 4B).

Efficacy of AAC00-1 $\Delta h r c$ as a seed treatment under growth-chamber conditions. Watermelon seed naturally infested with $A$. citrulli displayed a mean BFB seedling transmission percentage of $55 \%$ ( $\pm 8 \%$ [standard error]) (Fig. 5A). In comparison, seed treated with AAC00-1 $\Delta h r c C$ displayed a BFB seedling transmission percentage of $10( \pm 3) \%$ by 12 dap, which was lower than that observed for AAA 99-2 (14 [ \pm 4$] \%$; Fig. 5A). Tukey-Kramer's HSD analysis indicated that BFB seedling transmission percentages for seed treated with AAA 99-2 and AAC00-1 $\Delta h r c C$ were significantly lower than for seed treated with PBS $(P<0.01)$. However, BFB seedling transmission for seed treated with AAC00$1 \Delta h r c C$ and AAA 99-2 were not significantly different $(P=0.8$; Fig. 5B). Seed treatment with AAC00-1 $\Delta h r c C$ delayed BFB symp-
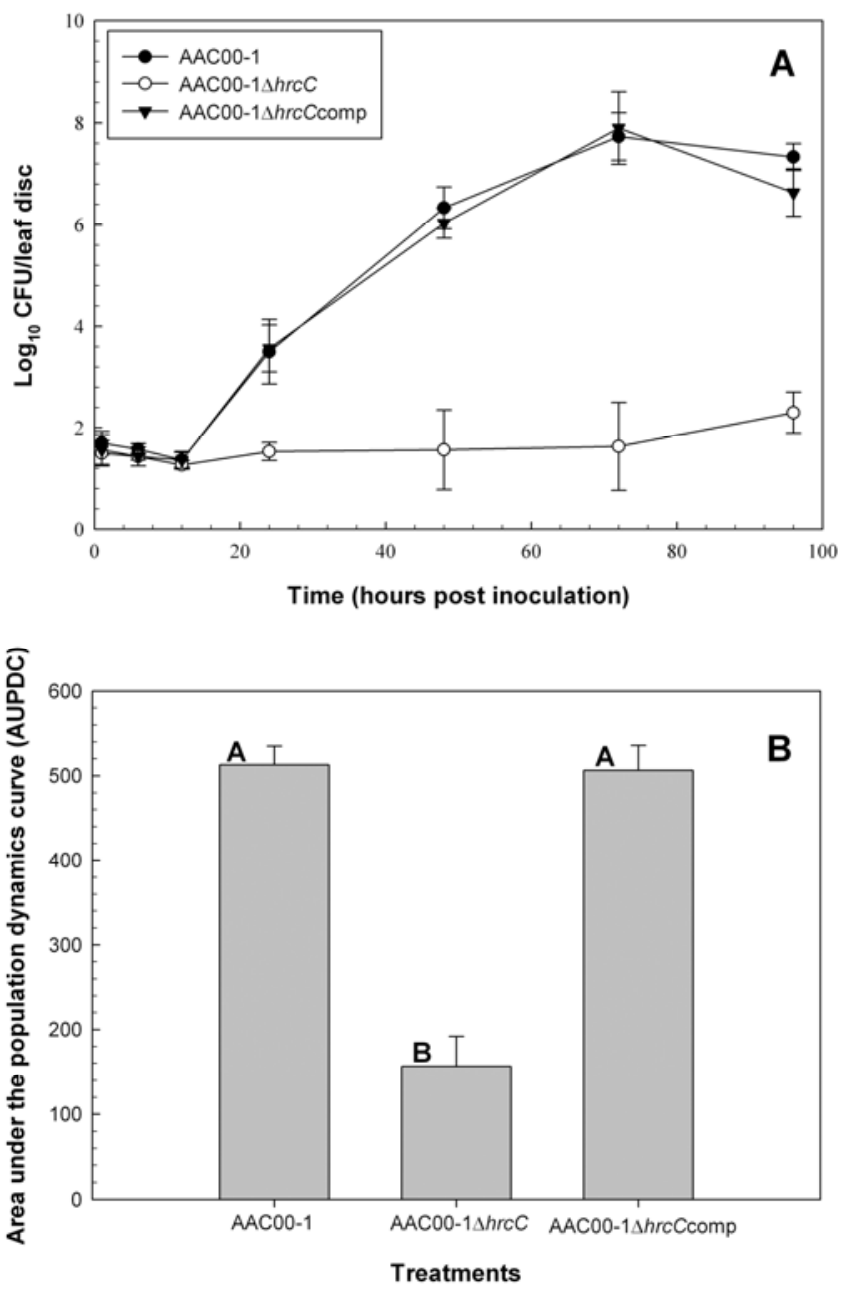

Fig. 4A, Colonization of watermelon seedlings ('Crimson Sweet') by Acidovorax citrulli (AAC00-1) (wild-type), AAC00-1 $\Delta h r c C$ ( $h r C C$ deletion mutant), and AAC00$1 \Delta h r c$ comp (complemented $h r c C$ mutant). The experiment was conducted three times and each data point represents the mean of three experiments $(n=6$ leaf discs/treatment). Lines represent the standard error of the means. B, Bar chart of area under population dynamics curve calculated for watermelon seedlings infiltrated with AAC00-1, AAC00-1 $\Delta h r C C$, or AAC00-1 $h$ hrcCcomp and incubated for 96 $h$. Bars represent the mean area under population dynamics curve and lines indicate standard error of the means. Treatments with different letters are significantly different according to Tukey-Kramer's honestly significant difference. 
tom expression by 2 days. When seed were treated with AAC00$1 \Delta h r c C$ and AAA $99-2$ BFB, seedling transmission was reduced by 81.8 and $74.6 \%$, respectively, compared with PBS.

Efficacy of AAC00-1 $\Delta h r c C$ as a seed treatment under greenhouse conditions. To determine the efficacy of AAC00-1 $\Delta h r c C$ as a seed treatment under transplant house conditions, seed naturally infested with AAC00-1 were treated and planted under greenhouse conditions highly conducive to BFB development. Seed treatment with AAC00-1 $4 h r c C$ reduced BFB seedling transmission and epidemic development relative to the negative control. For naturally infested seed treated with PBS, mean BFB seedling transmission percentage was $37( \pm 3) \%$ (Fig. 6A). In contrast, seed treated with AAC00-1 $\Delta h r c$ displayed $23( \pm 7) \%$ BFB incidence by 21 dap (Fig. 6A), which represents a $37.8 \%$ reduction relative to PBStreated seed. BFB seedling transmission for seed treated with AAC00-1 $\Delta h r c C$ was significantly lower than for PBS-treated seed $(P=0.02)$ according to the Student's $t$ test. BFB transmission for AAC00-1 $\Delta h r c C$-treated seed was delayed by 5 days in the greenhouse compared with 2 days in the growth chamber.

Efficacy of AAC00-1 $\Delta$ hrcC as a blossom protectant against seed infestation by $\boldsymbol{A}$. citrulli. Watermelon fruit produced from female blossoms protected with AAC00-1 $\Delta h r c C$ or AAA 99-2 and
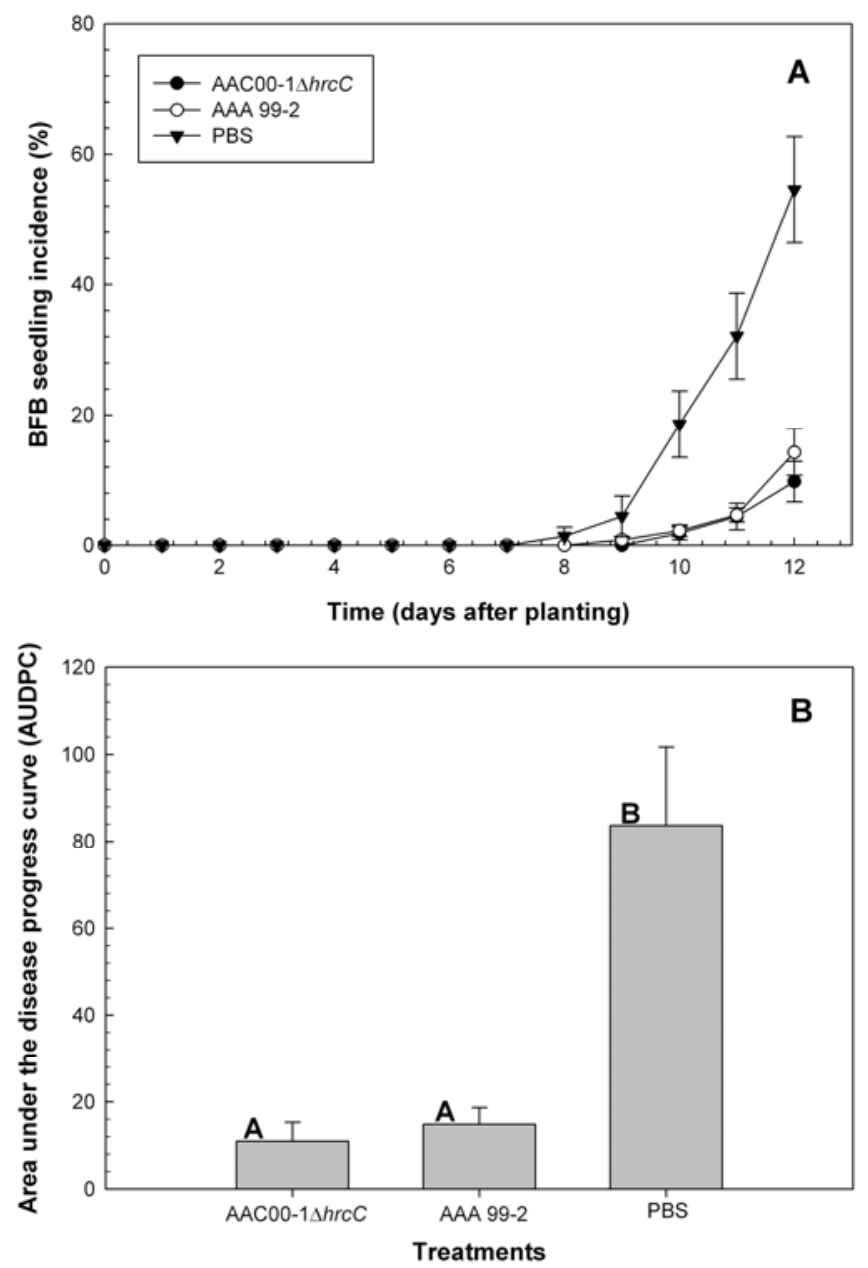

Fig. 5A, Comparison of the effect of seed treatments with Acidovorax citrulli AAC00-1 1 hrcC (type III secretion system mutant), A. avenae (AAA 99-2), or $0.1 \mathrm{M}$ phosphate-buffered saline (PBS, negative control) on bacterial fruit blotch (BFB) seedling transmission for watermelon seed naturally infested with $A$. citrulli. Data points represent the mean BFB seedling transmission percentage of two experiments ( $n=100$ seeds/treatment) and the lines represent the standard error of the means. B, Bar chart of area under disease progress curves (AUDPCs) calculated for naturally infested seed treated with AAC00-1 $h r c C$, AAA99-2, or PBS. Bars represent mean AUDPC values and lines indicate standard error of the means. Treatments with different letters are significantly different according to TukeyKramer's honestly significant difference. subsequently challenged with AAC00-1 did not develop BFB symptoms at harvest maturity. Based on ANOVA, the effect of experiment on seed infestation was not significant $(P=0.64)$; hence, the data for the two experiments were pooled for analysis. Blossom protection with biocontrol agents reduced seed infestation by $A$. citrulli and this effect was statistically significant $(P<0.01)$. Approximately $36 \%$ of seed produced from blossoms protected with PBS developed BFB symptoms in the modified seedling grow-out assay. In comparison, seedlots produced from blossoms protected with AAA 99-2 and AAC00-1 $\Delta h r c C$ had mean BFB seedling transmission percentages of 4 and $8 \%$, respectively (Fig. 7). Tukey-Kramer's HSD analysis indicated that A. citrulli infestation for seed from blossoms protected with AAC00-1 $\Delta h r c C$ or AAA 99-2 was significantly less than for those treated with PBS $(P$ $<0.01$; Fig. 7). However, there was no significant difference between the abilities of AAC00-1 $\Delta h r c C$ and AAA 99-2 to limit seed infestation by $A$. citrulli $(P=0.8)$. ANOVA of seed germination percentage data indicated that the effect of experiment was statistically significant $(P=0.002)$. Hence, the data for the two experiments were analyzed separately. In experiment 1 , mean germination percentages were 91,86 , and $81 \%$ for seed from blossoms protected with PBS, AAA 99-2, and AAC00-1 $4 h r c$, respectively.
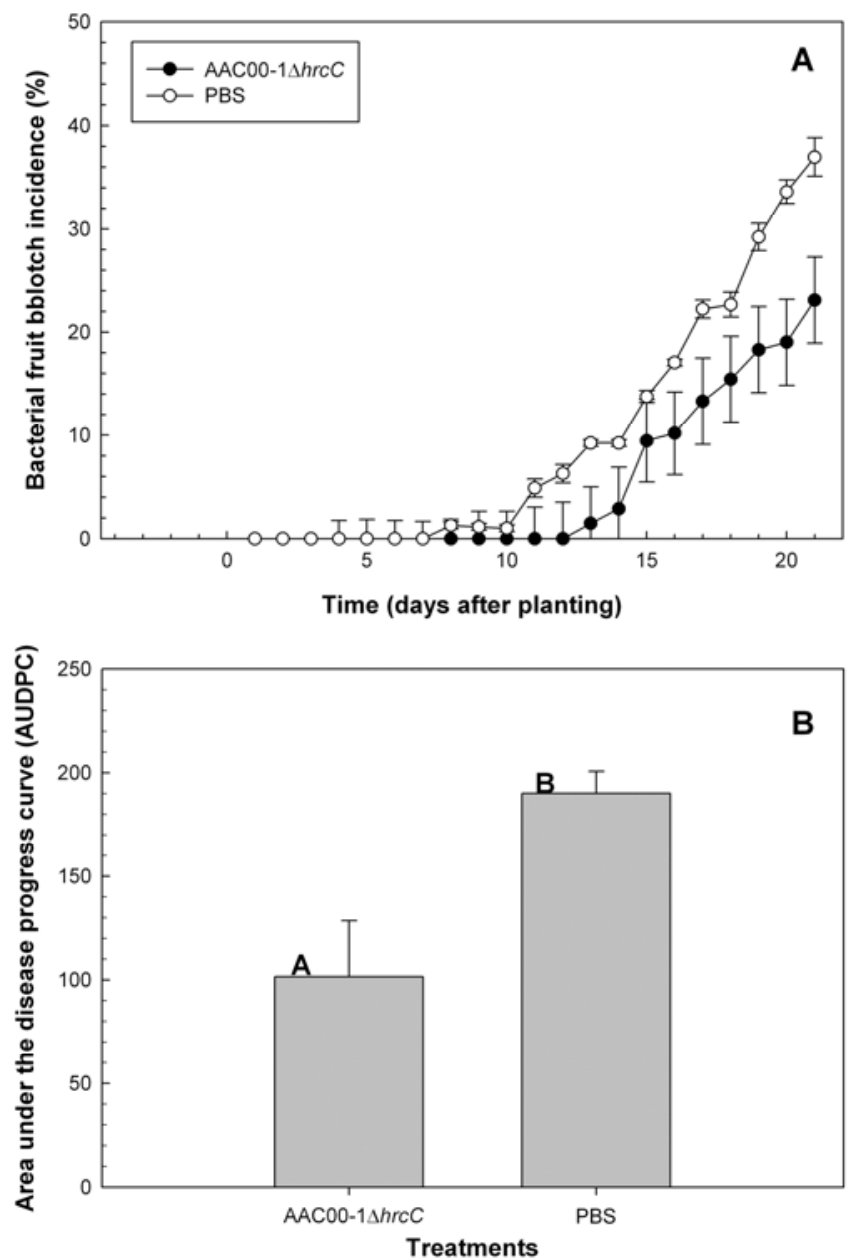

Fig. 6A, Effect of seed treatment with Acidovorax citrulli AAC00-1 4 hrcC (type III secretion system mutant) or $0.1 \mathrm{M}$ phosphate-buffered saline (PBS, negative control) on Bacterial fruit blotch (BFB) seedling transmission for watermelon seed naturally infested with $A$. citrulli under greenhouse conditions. Each data point represents the mean BFB seedling transmission for three experiments $(n=100$ seeds/treatment) and the lines represent the standard error of the means. B, Bar chart of area under disease progress curves (AUDPCs) calculated for $A$. citrulliinfested watermelon seed treated with AAC00-1 1 hrcC or PBS grown under greenhouse conditions for 21 days. Bars represent mean AUDPC values and lines indicate standard error of the means. Treatments with different letters are significantly different according to the Student's $t$ test. 
In experiment 2, seed from blossoms treated with PBS, AAA 99-2, or AAC00-1 $\Delta h r c C$ displayed 98,97 , and $89 \%$ germination, respectively. For both experiments, the differences in germination percentages for seed from blossoms protected with PBS, AAA 99-2, or AAC00-1 $\Delta h r c C$ were not statistically significant (experiment 1 , $P=0.095$; experiment $2, P=0.08$ ).

Efficiency of seed treatment via female watermelon blossom inoculation. AAC00-1 $h r c C$ retained its ability to colonize blossoms and infest watermelon seed compared with wild-type AAC00-1. In total, $100 \%$ of the seedlots produced in fruit from AAC00-1- or AAC00-1 $\Delta h r c C$-inoculated blossoms were infested. AAC00-1 $\Delta h r c C$-infested seedlots had populations that ranged from $10^{2}$ to $10^{4} \mathrm{CFU} / \mathrm{g}$ of seed. In comparison, bacterial populations on AAC00-1-infested seedlots ranged from $10^{3}$ to $10^{4} \mathrm{CFU} / \mathrm{g}$. The mean bacterial populations for seedlots infested with AAC00-1 $\left(2.1 \times 10^{4} \mathrm{CFU} / \mathrm{g}\right)$ were not significantly different from those for AAC00-1 $\Delta h r c C$-infested seedlots $\left(1.2 \times 10^{4} \mathrm{CFU} / \mathrm{g}\right)(P=0.33)$.

\section{Discussion}

In this study, we confirmed that $A$. citrulli has a functional T3SS encoded by the $h r p$ gene cluster. $h r c C$ encodes a multimeric protein that forms the outer membrane pore of the T3SS (6). Deletion of $h r c C$ in AAC00-1 abolished pathogenicity on watermelon seedling tissues and the ability to induce an HR on tobacco plants. These observations suggest that the T3SS is required for foliar pathogenicity. As expected, complementation of the deleted $h r c C$ gene restored functionality of the T3SS. Although this is the first report of a functional T3SS in A. citrulli, it was expected because T3S has been reported for other phytopathogenic bacteria $(1,24,34)$.

Biological control of plant diseases usually involves competition for nutrients or colonization sites, or antibiosis $(20,31)$. The ability of a nonpathogenic T3SS A. citrulli mutant, AAC00-1 $\Delta h r c C$, to colonize seed was assessed to determine whether it could compete with wild-type bacteria during seed germination and, thereby, limit BFB seedling transmission. AAC00-1 $\Delta h r c C$ retained its ability to colonize germinating watermelon seed and, by $96 \mathrm{~h}$ after planting, its populations were not significantly different to those of AACO01 or AAC00- $1 \Delta h r c C$ comp. The ability of a T3SS mutant of a phytobacteria to colonize seed at wild-type rates has been previously reported for Pseudomonas syringae pv. syringae B728a on bean (14). Similar to this study, Hirano et. al. (14) reported that disruption of the T3SS did not affect colonization of the germinating bean seed. Based on these observations, we conclude that type III effector proteins are not essential for seed colonization by $A$. citrulli during seed germination. It is logical to conclude that, during the initial phases of germination, seedborne phytobacteria grow as epiphytes rather than as plant pathogens.

When applied as a seed treatment to naturally infested watermelon seed, AAC00-1 $\Delta h r c C$ suppressed BFB seedling transmission similarly to AAA 99-2, a strain previously reported to be antagonistic to A. citrulli. Under greenhouse conditions, AAC00$1 \Delta h r c C$ seed treatments delayed the onset of BFB symptoms on watermelon seedlings. Interestingly, we observed better suppression of BFB seedling transmission in the growth chamber (5.5-fold reduction) than in the greenhouse assay (1.6-fold reduction). This was unexpected because conditions in the growth-chamber assay were consistently highly conducive for BFB seedling transmission, whereas conditions in the greenhouse (namely, relative humidity) were less conducive. Because plants were allowed to grow for 21 versus 12 days in the greenhouse experiment, we concluded that the biocontrol efficacy of AAC00-1 $\Delta h r C C$ declined as the seedlings matured. This was likely due to the inability of the mutant to colonize older watermelon foliage and compete with AAC00-1 once it entered the pathogenic phase.

Pollination of blossoms leads to the production of stigmatic exudates, including sugars and proteins, that make the blossom an ideal environment for A. citrulli colonization (12). A. citrulli can colonize and penetrate female watermelon blossoms, which can lead to seed infestation without BFB fruit symptoms $(18,36)$. We observed that $h r c C$ was not critical for blossom colonization and penetration because AAC00-1 $h r c C$ was not affected in its ability to infest seed via this pathway. In two independent experiments, $100 \%$ of seedlots generated from blossoms treated with AAC00$1 \Delta h r c C$ were inoculated. Seed infestation levels for blossoms treated with AAC00-1 $\Delta h r c C$ and AAC00-1 were not significantly different. In contrast, Darsonval et al. (7) reported that T3SS mutants of X. fuscans subsp. fuscans were impaired in their ability to be transmitted to bean seed via blossoms. This discrepancy might be explained by differences in the morphology of watermelon and bean flowers and the unique nature of the host-pathogen interactions. In the case of watermelon and A. citrulli, it is likely that the interaction is nonspecific and colonization and invasion of blossoms occurs passively. This explanation is supported by the observation that Pantoea ananatis, a seedborne onion phytobacterium that is nonpathogenic on watermelon, colonized blossoms and infested watermelon seed (40). Lessl et al. (23) also reported that Pseudomonas syringae cit7, an epiphyte recovered from tomato foliage, also colonized watermelon stigmas. It would be interesting to determine whether bean flowers could be colonized and invaded by phytobacteria that were not bean pathogens.

The ability of T3SS mutants of phytobacteria to limit plant diseases caused by their pathogenic progenitors has been reported for $X$. campestris pv. vesicatoria and $P$. syringae pv. tomato $(27,43)$. Moss et al. (27) found that $h r p$ regulatory mutants were more effective than structural mutants due to the induction of host defense responses that are greater in the presence of regulatory mutants (27). Because watermelon blossom and seed colonization does not require the T3SS, it is unlikely that $h r p$ regulatory mutants of $A$. citrulli would improve biocontrol activity as seed or blossom treatments. However, regulatory mutants of $A$.citrulli might improve biocontrol activity on seedling or mature foliar tissues.

Chemical seed treatments have had limited efficacy in BFB management, most likely because $A$. citrulli may be present under the seed coat $(18,30)$. One advantage of AAC00-1 $\Delta h r c C$ is its ability to infest seed in a manner similar to wild-type $A$. citrulli and, thereby, become localized in similar seed tissues as the pathogen. Although the exact mechanism of biological control is unknown, we suspect that AAC00-1 $\Delta h r c C$ competes with wild-type $A$. citrulli for nutrients and colonization sites on the germinating seed-

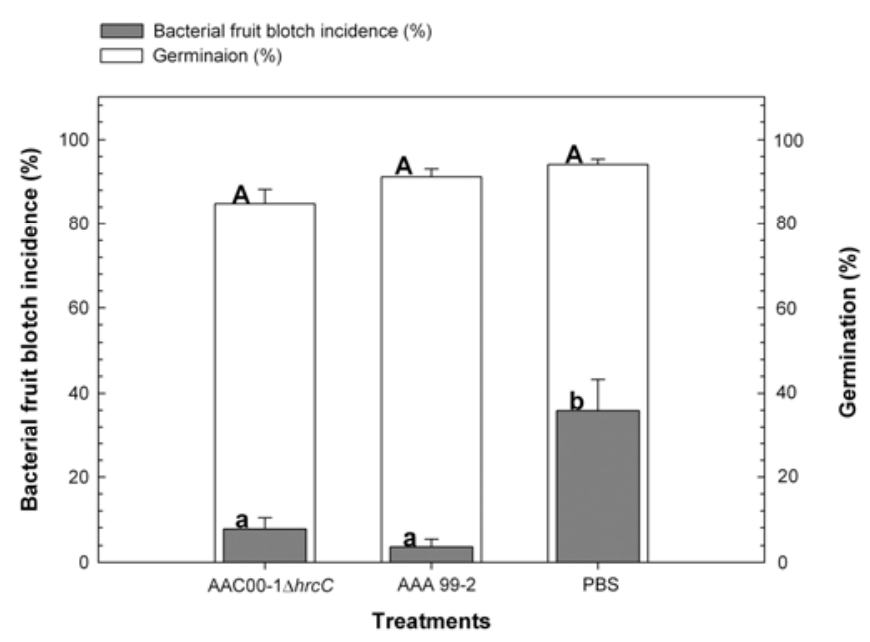

Fig. 7. Effect of female watermelon blossom protection with Acidovorax citrulli AAC00-1 $\Delta$ hrcC (type III secretion system mutant), A. avenae (AAA 99-2), or $0.1 \mathrm{M}$ phosphate-buffered saline (PBS, negative control) on bacterial fruit blotch (BFB) seedling transmission and seed germination percentages. The experiment was conducted three times and bars represent the mean BFB incidence or germination for two experiments ( $n=100$ seeds/treatment). Lowercase letters represent the comparison of effects of blossom treatments on BFB seedling transmission, while uppercase letters indicate the results for comparing the effects of seed treatments on germination. Treatments with different letters are significantly different according to Tukey-Kramer's honestly significant difference. 
ling. AAC00-1 $\mathrm{AhrC}$ can also be used as a blossom protectant to limit seed infestation in seed production fields. In hybrid seed production, lyophilized AAC00-1 $\mathrm{hrcC}$ cells could be introduced into female blossoms during hand pollination without the need for added operational steps. Unfortunately, it is unlikely that blossom protection with AAC00-1 $4 h r c$ could be a stand-alone treatment for BFB because it did not completely eliminate BFB seedling transmission. Nevertheless, blossom protection followed by seed treatment with AAC00-1 $4 h r c C$ might represent an important component in a comprehensive integrated BFB management strategy that seeks to deemphasize the use of xenobiotic pest management chemicals (i.e., organic cucurbit seed production). Benefits may also be gained by developing and exploring more effective strategies and techniques for applying biocontrol agents to seed or blossoms.

\section{Acknowledgments}

We thank T. Denny, M. Schell, and A. Castro-Sparks for their technical input; and P. Chebrulo and B. Dutta for technical assistance.

\section{Literature Cited}

1. Alfano, J. R., and Collmer, A. 1997. The type three secretion pathway of plant pathogenic bacteria: trafficking harpins, Avr proteins, and death. J. Bacteriol. 179:5655-5662.

2. Bahar, O., Kritzman, G., and Burdman, S. 2009. Bacterial fruit blotch of melon: screens for disease tolerance and role of seed transmission in pathogenicity. Eur. J. Plant Pathol. 123:71-83.

3. Bonas, U. 1994. hrp Genes of phytopathogenic bacteria. Curr. Top. Microb. Immunol. 192:79-98.

4. Burdman, S., Kots, N., Kritzman, G., and Kopelowitz, J. 2005. Molecular, physiological, and host-range characterization of Acidovorax avenae subsp. citrulli isolates from watermelon and melon in Israel. Plant Dis. 89:13391347.

5. Collmer, A., and Bauer, D. W. 1994. Erwinia chrysanthemi and Pseudomonas syringae: plant pathogens trafficking in extracellular virulence proteins. Curr. Top. Microb. Immunol. 192:43-78.

6. Cornelis, G. R., and Van Gijsegem, F. 2000. Assembly and function of type III secretory systems. Annu. Rev. Microbiol. 54:735-774.

7. Darsonval, A., Darrasse, A., Meyer, D., Demarty, M., Durand, K., Bureau, C., Manceau, C., and Jacques, M. A. 2008. The type III secretion system of Xanthomonas fuscans subsp. fuscans is involved in the phyllosphere colonization process and in transmission to seeds of susceptible beans. Appl. Environ. Microbiol. 74:2669-2678.

8. De Feyter, R., and Gabriel, D. W. 1991. Use of cloned DNA methylase genes to increase the frequency of transfer of foreign genes into Xanthomonas campestris pv. malvacearum. J. Bacteriol. 173:6421-6427.

9. Fessehaie, A., and Walcott, R. R. 2005. Biological control to protect watermelon blossoms and seed from infection by Acidovorax avenae subsp. citrulli. Phytopathology 95:413-417.

10. Frankle, W. G., Hopkins, D. L., and Stall, R. E. 1993. Ingress of the watermelon fruit blotch bacterium into fruit. Plant Dis. 77:1090-1092.

11. Ha, Y., Fessehaie, A., Ling, K. S., Wechter, W. P., Keinath, A. P., and Walcott, R. R. 2009. Simultaneous detection of Acidovorax avenae subsp. citrulli and Didymella bryoniae in cucurbit seedlots using magnetic capture hybridization and real-time polymerase chain reaction. Phytopathology 99:666-678.

12. Hawker, J. S., Sedgley, M., and Loveys, B. R. 1983. Composition of stigmatic exudate, nectar and pistil. Aust. J. Plant Physiol. 10:257-264.

13. He, S. Y., Nomura, K., and Whittam, T. S. 2004. Type III protein secretion mechanism in mammalian and plant pathogens. Biochim. Biophys. Acta 1694:181-206

14. Hirano, S. S., Charkowski, A. O., Collmer, A., Willis, D. K., and Upper, C. D. 1999. Role of the Hrp type III protein secretion system in growth of Pseudomonas syringae pv. syringae B728a on host plants in the field. Proc. Natl. Acad. Sci. USA 96:9851-9856.

15. Hopkins, D. L., Cucuzza, J. D., and Watterson, J. C. 1996. Wet seed treatments for the control of bacterial fruit blotch of watermelon. Plant Dis. 80:529-532.

16. Hopkins, D. L., Lovic, B., Hilgren, J., and Thompson, C. M. 2003. Wet seed treatment with peroxyacetic acid for the control of bacterial fruit blotch and other seedborne diseases of watermelon. Plant Dis. 87:1495-1499.

17. Hopkins, D. L., and Thompson, C. M. 2001. Evaluation of Citrullus sp. germplasm for resistance to Acidovorax avenae subsp. citrulli. Plant Dis. 86:61-64.

18. Hopkins, D. L., and Thompson, C. M. 2002. Seed transmission of Acidovorax avenae subsp. citrulli in cucurbits. HortScience 37:924-926.

19. Huguet, E., Hahn, K., Wengelnik, K., and Bonas, U. 1998. hpaA mutants of Xanthomonas campestris pv. vesicatoria are affected in pathogenicity but retain the ability to induce host-specific hypersensitive reaction. Mol. Microbiol. 29:1379-1390.

20. Knudsen, I. M. B., Hockenhull, J., Funck Jensen, D., Gerhardson, B., Höke- berg, M., Tahvonen, R., Teperi, E., Sundheim, L., and Henriksen, B. 1997. Selection of biological control agents for controlling soil and seed-borne diseases in the field. Eur. J. Plant Pathol. 103:775-784.

21. Kobayashi, D. Y., Tamaki, S. J., and Keen, N. T. 1989. Cloned avirulence genes from the tomato pathogen Pseudomonas syringae pv. tomato confer cultivar specificity on soybean. Proc. Natl. Acad. Sci. USA 86:157-161.

22. Koster, M., Bitter, W., deCock, H., Allaoui, A., Cornelis, G. R., and Tommassen, J. 1997. The outer membrane component, YscC, of the Yop secretion machinery of Yersinia enterocolitica forms a ring-shaped multimeric complex. Mol. Microbiol. 26:789-797.

23. Lessl, J. T., Fessehaie, A., and Walcott, R. R. 2007. Colonization of female watermelon blossoms by Acidovorax avenae ssp. citrulli and the relationship between blossom inoculum dosage and seed infestation. J. Phytopathol. 155:114-121.

24. Lindgren, P. B., Peet, R. C., and Panopoulos, N. J. H. 1986. Gene cluster of Pseudomonas syringae pv. phaseolicola controls pathogenicity on bean plants and hypersensitive response on nonhost plants. J. Bacteriol. 168:512-522.

25. Medeiros, F. H. V., Moraes, I. S. F., da Silva Neto, E. B., Silveira, E. B., and de Lima R. Mariano, R. 2009. Management of melon bacterial blotch by plant beneficial bacteria. Phytoparasitica 37:453-460.

26. Mirik, M., Aysan, Y., and Sabin, F. 2006. Occurrence of bacterial fruit blotch of watermelon caused by Acidovorax avenae subsp. citrulli in the Eastern Mediterranean region of Turkey. Plant Dis. 90:829-829.

27. Moss, W. P., Byrne, J. M., Campbell, H. L., Ji, P., Bonas, U., Jones, J. B., and Wilson, M. 2007. Biological control of bacterial spot of tomato using hrp mutants of Xanthomonas campestris pv. vesicatoria. Biol. Control 41:199-206.

28. Neipold, F., Anderson, D., and Mills, D. 1985. Cloning determinants of pathogenesis from Pseudomonas syringae pathovar syringae. Proc. Natl. Acad. Sci. USA 82:406-410.

29. Palkovics, L., Petroczy, M., Kertesz, B., Nemeth, J., Barsony, C., Mike, Z., and Hevesi, M. 2008. First report of bacterial fruit blotch of watermelon caused by Acidovorax avenae subsp. citrulli in Hungary. Plant Dis. 92:834 835 .

30. Rane, K. K., and Latin, R. X. 1992. Bacterial fruit blotch of watermelon: association of the pathogen with seed. Plant Dis. 76:509-512.

31. Roberts, D. P., Stromberg, E. L., Lacy, G. H., and Buyer, J. S. 1999. Biological disease control: considerations for seed treatment and stand establishment. Acta Hortic. 504:69-74.

32. Schaad, N. W., Postnikova, E., and Randhawa, P. 2003. Emergence of Acidovorax avenae subsp. citrulli as a crop-threatening disease of watermelon and melon. Pages 573-581 in: Presentations 6th Int. Conf. Pseudomonas syringae Pathovars and Related Pathogens. N.W. Schaad, ed. Kluwer Press, Maratea, Italy.

33. Schaad, N. W., Postnikova, E., Sechler, A., Claflin, L. E., Vidaver, A. K Jones, J. B., Agakova, I., Ignatov, A., Dickstein, E., and Ramundo, B. A. 2008. Reclassification of subspecies of Acidovorax avenae as A. avenae (Manns 1905) emend., A. cattleyae (Pavarino, 1911) comb. nov., A. citrulli (Schaad et. al.,1978) comb. nov., and proposal of A. oryzae sp. nov. Syst. Appl. Microbiol. 31:434-446.

34. Schulte, R., and Bonas, U. 1992. Expression of the Xanthomonas campestris pv. vesicatoria hrp gene cluster, which determines pathogenicity and hypersensitivity on pepper and tomato, is plant inducible. J. Bacteriol. 174:815-823.

35. Somodi, G. C., Jones, J. B., Hopkins, D. L., Stall, R. E., Kucharek, T. A., Hodge, N. C., and Watterson, J. C. 1991. Occurrence of a bacterial watermelon fruit blotch in Florida. Plant Dis. 75:1053-1056.

36. Sowell, G., and Schaad, N. W. 1979. Pseudomonas pseudoalcaligenes subsp. citrulli on watermelon: seed transmission and resistance of plant introductions. Plant Dis. Rep. 63:437-441.

37. Tharaud, M., Laurent, J., Faize, M., and Paulin, J. 1997. Fire blight protection with avirulent mutants of Erwinia amylovora. Microbiology 43:625632.

38. Trigalet, A., Trigalet-Demetry, D., and Feuillade, R. 1998. Aggressiveness of French isolates of Ralstonia solanacearum and their potential use in biocontrol. Bull. OEPP/EPPO Bull. 28:101-107.

39. Walcott, R. R., Castro, A. C., Fessehaie, A., and Ling, K. 2006. Progress towards commercial-scale detection of $A$. avenae subsp. citrulli in cucurbit seed using immunomagnetic separation and the polymerase chain reaction. Seed Sci. Technol. 34:101-116.

40. Walcott, R. R., Gitaitis, R. D., and Castro, A. C. 2003. Role of blossoms in watermelon seed infestation by Acidovorax avenae subsp. citrulli. Phytopathology 93:528-534.

41. Wang, X., Li, G., Jiang, D., and Huang, H. 2009. Screening of plant epiphytic yeasts for biocontrol of bacterial fruit blotch (Acidovorax avenae subsp. citrulli) of hami melon. Biol. Control 50:164-171.

42. Willems, A., Goor, M., Thielemans, S., Gillis, M., Kersters, K., and De Ley, J. 1992. Transfer of several phytopathogenic Pseudomonas species to Acidovorax as Acidovorax avenae subsp. avenae subsp. nov., comb. 'nov. Acidovorax avenae subsp. citrulli, Acidovorax avenae subsp. cattleyae, and Acidovorax konjaci. Int. J. Syst. Bacteriol. 42:107-119.

43. Wilson, M., Campbell, H. L., Ji, P., Jones, J. B., and Cuppels, D. A. 2002. Biological control of bacterial speck of tomato under field conditions at several locations in North America. Phytopathology 82:1284-1292. 